\title{
The Proliferation of Disputes, Dispute Settlement Procedures and Respect for the Rule of Law
}

\author{
by THOMAS BUERGENTHAL*
}

IT IS truly a great pleasure for me to be here with you this evening. I must admit, however, that I feel a little bit like the lawyer who comes home late one evening totally drunk. His wife meets him at the door and screams, "what have you to say for yourself?' He looks at her in total innocence and mumbles: 'I don't really have anything to say, but I would be pleased to entertain questions'.

Unlike the lawyer in this story; I attribute my problem not to alcohol but to the topic assigned to me, "The proliferation of disputes, dispute settlement procedures and respect for the rule of law'. Your colloquium organisers very kindly gave me this broad topic to allow me to speak about anything I wanted to, and for that I am most grateful. But, of course, this broad topic creates its own problem: what specifically to speak about.

Clearly, we have been witnessing a proliferation of disputes as well as a proliferation of dispute settlement procedures. I doubt, though, that respect for the rule of law has kept up with the proliferation of disputes and dispute settlement procedures, and I will have something to say on this subject in a moment, but let me first say a word about the proliferation of disputes and dispute settlement mechanisms.

A story frequently told in American law schools runs something like this: a young lawyer moves into a small town that has not had a local lawyer for some years. The newcomer figures that he will become rich fast since he will get all local legal business. But contrary to his expectations, he is not doing very well and is ready to move to a larger city. But then another lawyer moves into town and both lawyers begin to prosper. Well, the moral of the story is that competing law firms create their own business dynamic or that more lawyers create more legal problems.

Something like this same dynamic accounts for the proliferation of disputes and dispute settlement mechanisms. Of course, I am simplifying. Clearly, the

* Judge, International Court of Justice. After-dinner speech delivered in conjunction with the Colloquium on Consolidation of Proceedings in Investment Arbitration, organised by Geneva University and PICT, 21--22 April 2006. 
growth of international travel, trade and communication, as well as globalisation in general, account in large measure for more disputes, whereas the need to resolve these disputes peacefully quite naturally leads to an increase in the number and types of dispute settlement procedures. Other relevant phenomena are the proliferation of international organisations that have sprung up since the Second World War as well as the internationalisation of the protection of human rights.

The human rights movement, for example, has led to the enactment of a large body of international human rights law, followed by the creation of judicial and quasi-judicial universal and regional institutions to resolve human rights disputes. This development has contributed to the growth of dispute settlement mechanisms not only in the human rights field, but in other areas of the law as well. I would guess, for example, that it helped the World Bank, when creating ICSID, that the practice of the European Commission and Court of Human Rights demonstrated early on that giving individuals standing to sue states did not have catastrophic consequences. Here it is also interesting to note that some of the reasons that motivated the creation of ICSID, including discriminatory governmental practices and laws, denials of due process, lengthy delays, corruption, etc., were not all that far removed from the problems that the European Convention on Human Rights was designed to address in the human rights context.

Of course, there are many other reasons for the proliferation of dispute resolution procedures and the growing resort to them by states. Europe has pioneered with the European Convention on Human Rights and its dispute settlement procedures. They were followed by the establishment of the InterAmerican Court of Human Rights and the African human rights system with its recently created African Court of Human and Peoples' Rights. Regional common market or economic courts have sprung up in different parts of the world, modelled on the Court of Justice of the European Union.

As I look at these and similar developments, I have the impression that at least two different phenomena are at work here. In the past, states were afraid of international courts and tribunals. These fears could be attributed in part at least to the relatively small volume of international legislation and jurisprudence on almost any international law subject. That, in turn, made it difficult for states to predict judicial outcomes of disputes with any degree of certainty. Over the years, that jurisprudence has grown significantly as a result of the increase in the number of international judicial institutions and the resultant growth of their case law. I think, for example, that while the end of the Cold War has had much to do with the increase in the caseload of the International Court of Justice, if only because states now have greater confidence in the impartiality of the judges, it may also be true that the Court's expanded docket is due in part to the greater predictability regarding the law the Court will apply to a given dispute. That predictability is the result of the Court's growing jurisprudence. In other words, more cases produce more jurisprudence, more jurisprudence produces more cases. What we have here is the chicken and the egg phenomenon. 
One other reason for the growth of dispute resolution mechanisms on the international plane has to do with what I would call the copy-cat factor. The success or notoriety of a dispute settlement mechanism established in one region of the world or by one international organisation, for example, will frequently lead to the creation of similar institutions in other parts of the world or within the framework of other international organisations. The driving force behind the copy-cat phenomenon tends usually to be the prestige of having such institutions because other more developed or more important regions have them. The phenomenon is also in evidence in the growing number of arbitral facilities being created in different parts of the world. Of course, they are also seen as moneymaking institutions.

Some have argued that the proliferation of dispute resolution mechanisms, particularly of universal and regional judicial institutions, may lead to the fragmentation of international law. I don't want to get into this controversial subject other than to note that I have argued elsewhere that the proliferation of international courts is, on the whole, good for international law. My simplistic view on this subject is that the growth of international judicial and quasi-judicial dispute mechanisms, particularly courts, whether regional or universal, leads to a creative interaction among such courts, helping to transform international law into a more vibrant and more relevant legal system than it has been in the past. I grant, of course, that there may be some fragmentation, but that is unavoidable and inherent in the interpretation or application of legal norms by different courts to different problems and at times even to the same problems. In this connection, I wonder whether fragmentation is the right word to describe this phenomenon. Might one not speak instead of the growing inclusiveness of international law or the broadening of the concept of international law?

Just one more word on this issue. I have long been fascinated by overt and covert interaction between international courts. There are very few ICSID tribunals, for example, that do not cite decisions of the International Court of Justice. When I was on the Inter-American Court of Human Rights, we looked to and often cited decisions of the European Court of Human Rights and the ICJ as well as the PCIJ. I can also assure you that the judges of the ICJ study the judgments of the European Court of Human Rights as well as the decisions of the International Criminal Tribunal for the Former Yugoslavia when they might be relevant to our work. In short, there is a great deal of interaction between international judicial and quasi-judicial bodies. That is good and there should be more of it. Informal contacts between the various courts should also be encouraged.

I turn to respect for the rule of law in the context of the proliferation of international disputes and international dispute settlement procedures. Here I believe we still have a long way to go. There is much I could say on the subject, but I am well aware that a good meal, together with a long rambling speech, will put even the most conscientious audience to sleep. So I shall be brief and focus on some due process of law issues which to me are inherent elements of the rule of law.

For example, I believe that insufficient attention is being paid to some conflict of interest issues that can arise in the selection of those who are called upon to 
settle disputes. Let me illustrate my point by reference to ICSID, since it is the arbitration facility I am most familiar with. I have long believed that the practice of allowing arbitrators to serve as counsel, and counsel to serve as arbitrators, raises due process of law issues. In my view, arbitrators and counsel should be required to decide to be one or the other, and be held to the choice they have made, at least for a specific period of time. That is necessary, in my opinion, in order to ensure that an arbitrator will not be tempted, consciously or unconsciously, to seek to obtain a result in an arbitral decision that might advance the interests of a client in a case he or she is handling as counsel. ICSID is particularly vulnerable to this problem because the interpretation and application of the same or similar legal instruments (the bilateral investment treaties, for example) are regularly at issue in different cases before it.

I also believe that repeated designations by counsel of the same arbitrator should be avoided. These revolving-door problems - counsel selecting an arbitrator who, the next time around when the arbitrator is counsel, selects the previous counsel as arbitrator - should be avoided. Manus manum lavat, in other words 'you scratch my back and I'll scratch yours', does not advance the rule of law.

Next, I have serious doubts regarding the wisdom of perpetuating the system of ad hoc judges, which is the rule in the ICJ and some other international tribunals. If you look at the separate opinions of ad hoc judges, you will rarely find any of them voting against the state that designated them. A much fairer system, in my opinion, would be to require the sitting national judges not to participate in the proceedings in which their country is a party to a case before the court, thus doing away with the need for ad hoc judges. (This rule applies in the newly created African Court of Human and Peoples' Rights.) I recognise, of course, that ad hoc judges are supposed, inter alia, to help the court understand the national law of the country that has designated them. It is worth noting here that in the case of the ICJ, for example, or that of the Inter-American Court of Human Rights, the tendency of states has been to name distinguished nonnationals rather than their own nationals as ad hoc judges. That suggests to me that the real reason for the designation of the ad hoc judge is not to help the court understand some relevant aspect of national law. In the ICJ, moreover, national law is seldom a relevant issue. I also do not think that ad hoc judges are needed to ensure that the court fully understand the arguments made by counsel for the parties. That is the job of counsel.

Further, having just gone through a re-election process, I am particularly conscious of the variety of problems the current system poses for judges seeking election or re-election to certain courts and tribunals, particularly within the United Nations system. What struck me in my re-election campaign is how highly politicised the election process is for the various judicial positions that the UN membership has to vote for and how little judicial qualifications of the individual candidates or their judicial record seem to matter. In my case, for example, one state very formally proposed to vote for me, provided the USA agreed to support that state's candidacy for a seat on the Security Council. I was honoured. 
Another problem that will have to be addressed at some point, I believe, has to do with the pressure that judicial candidates wishing to be renominated are likely to experience when they have to vote in a case in which their state of nationality is a party. That is another reason why, as I indicated a minute ago, I would prefer for national judges not to participate in cases involving their own country. The problem might also be dealt with by limiting judges to one term only, possibly one longer single term.

Finally, I also believe that there is a genuine need for the development and adoption of strict ethical standards applicable to judges and counsel in international tribunals. Existing standards are much too lax. They are even more difficult to enforce. The proliferation of international disputes and international dispute resolution mechanisms requires that the international community pay much closer attention than in the past to the ethical standards necessary to ensure that the rule of law is observed in the settlement of international disputes.

There is much more to be said on all these subjects, but the time has come for me to stop talking. 
